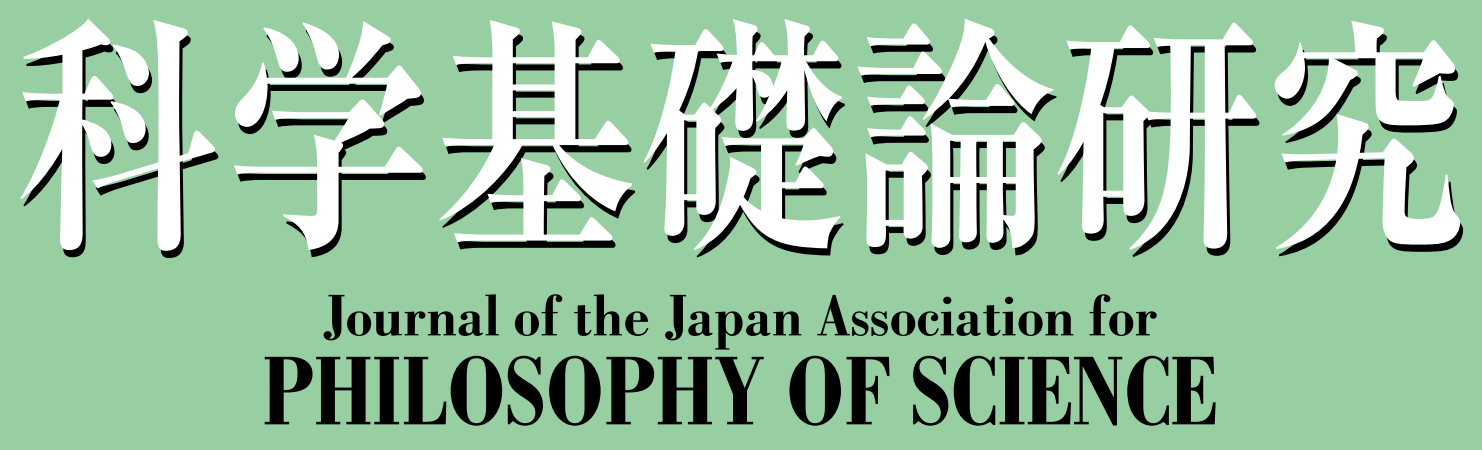

\author{
2020 年 \\ 第 47 巻 第 2 号
}

論 文

表現型についての遺伝情報は存在するのか

一目的意味論の観点から- ……………... 石田知子（1

最大共通要素をたてる見方に抗うということ

ーマクダウェルの選言説の解明と評価 - …… 小川祐輔 (23)

$$
\text { サーベイ論文 }
$$

技術的進歩と民主的社会变革の融合の可能性

一テクノ進歩派によるエンハンスメントの

正当化の試み_………………………堀内進之介 (39)

\title{
学会活動報告
}

2018 年度奖励賞選考結果

2019 年度秋の研究例会プログラム 


\section{PHILOSOPHY OF SCIENCE}

\section{Vol.47, No.2}

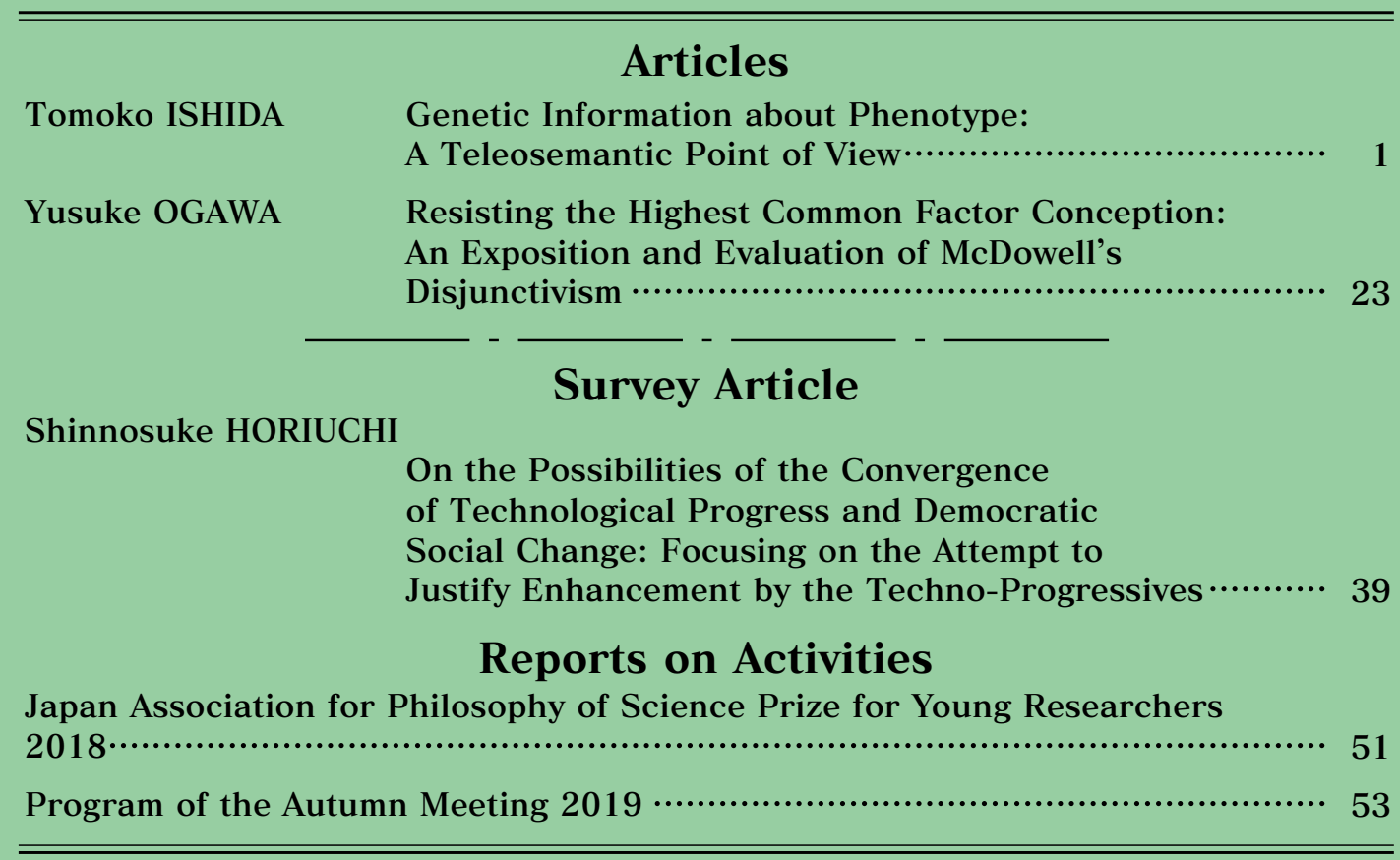

Published semi-annually by the Japan Association for PHILOSOPHY OF SCIENCE

c/o SASAKI PRINTING \& PUBLISHING CO., LTD.,

MCK BUILDING 2F, SHIBAURA 2-14-13, MINATO-KU, TOKYO 108-0023, JAPAN

E-MAIL: kisoron@sasappa.co.jp 